\title{
Analysis of the vaccination status of older adults
}

\author{
Análise da situação vacinal de idosos \\ Análisis de la situación vacunal de los adultos mayores
}

Pollyana Cristina dos Santos Ferreira $^{1}$

(D) Nayara Gomes Nunes Oliveira ${ }^{1}$
(D) Darlene Mara dos Santos Tavares ${ }^{1}$
(D) Daniele Cristina Marques
Machado $^{1}$

${ }^{1}$ Universidade Federal do Triângulo Mineiro, Uberaba, MG, Brazil.

\begin{abstract}
Objective: To describe the sociodemographic characteristics, functional capacity and vaccination status of older adults, and to verify the factors associated with the incomplete vaccination status and the absence of the vaccination card. Method: Cross-sectional and analytical study conducted with older adults living in the city of Uberaba (MG). The following analyzes were carried out: descriptive, bivariate and multinomial logistic regression ( $\mathrm{p}<0.05)$. Results: A total of 576 older adults participated. Most of them were women, in the 70-80 age group, with partner, low education and income, living with someone, independent in basic activities of daily living and with partial dependence on instrumental activities. The highest percentage was for older adults who had incomplete vaccination status, especially regarding the absence of immunization for Hepatitis $B$. Individual monthly income $\leq 1$ minimum wage $(\mathrm{p}=0.002)$ and single-person housing arrangement $(p=0.010)$ were associated with the incomplete vaccination status, and the absence of the vaccination card, with the lowest level of education $(p=0.039)$. Conclusion: Low income and education, as well as living alone, are factors associated with inadequate vaccination status among older adults in the community. The need for primary care nurses to develop strategies to increase vaccination coverage among older adults with these characteristics is emphasized.
\end{abstract}

DESCRIPTORS

Aged; Vaccines; Immunization; Health of the Elderly; Geriatric Nursing. 


\section{INTRODUCTION}

The increase in longevity is a global phenomenon, which has occurred differently in several countries. This change in the demographic profile ends up being reflected in new demands to be faced by the health sector, since in this age group, in general, there is a higher frequency of morbidities, functional disabilities and the need for access to more specialized and higher-cost services ${ }^{(1-2)}$. With advancing age, the occurrence of infectious diseases can also increase and vaccination becomes essential, since it is the best strategy for coping with immunopreventable infections ${ }^{(2)}$.

In this perspective, the Ministry of Health ${ }^{(3)}$ recommends older adults to be immunized with Hepatitis B vaccines, Diphtheria and Tetanus (dT), Yellow Fever, upon evaluation by the physician for those who are at risk of contracting the disease, and Seasonal Influenza (H1N1). The evaluation and monitoring of the vaccination status of older adults, by health professionals, especially nurses, favor the establishment of actions to prevent immunopreventable diseases, and consequently, contribute to the reduction of complications and hospitalization rates ${ }^{(2)}$.

Brazil stands out as one of the countries in the world where vaccines are more widely available to the population ${ }^{(3)}$. However, the lack of adherence of older adults to this health practice, found in national ${ }^{(2,4)}$ and international ${ }^{(5-6)}$ surveys, expresses the need for further investigations. In addition, the associations of socioeconomic factors and health conditions were verified in relation to the vaccination status of older adults, but with a focus on adherence to the Seasonal Influenza vaccine ${ }^{(2,4,7)}$. It is observed that research on this theme is still incipient, especially the assessment of older adults' vaccination status and associated factors ${ }^{(5,8)}$. Thus, the expansion of knowledge becomes relevant, in view of its contribution to the development of strategies to increase vaccination coverage among older adults.

Considering the above, the relevance of vaccination in minimizing the risk of illness and complications from immunopreventable infections, in addition to the hypothesis that sociodemographic factors and functional independence are related to the vaccination status of older adults, is considered. Thus, this study aimed to describe the sociodemographic characteristics, functional capacity and vaccination status of older adults, as well as to verify the factors associated with the incomplete vaccination status and the absence of the vaccination card of older adults.

\section{METHOD}

\section{TYPE OF STUDY}

This is a quantitative approach, household survey, crosssectional and analytical study type.

\section{SCENARIO}

This study was developed in the city of Uberaba, Minas Gerais state and is part of a larger project, entitled "Active Aging, Global Functionality and Life Quality among older adults in the Uberaba Health Region (MG)".

\section{SELECTION CRITERIA}

The inclusion criteria were: being 60 years old or older and living in the city of Uberaba (MG). Older adults with cognitive decline who had severe sequelae from stroke with localized loss of strength and aphasia, Parkinson's disease in severe or unstable stage with severe impairment of motor skills, speaking, hearing and/or affectivity were excluded, as it would make evaluations impossible.

\section{SAMPLE}

The population, selected by a multi-stage conglomerate sampling process, was made up of older adults living in the city of Uberaba (MG). The sample size calculation considered a prevalence of incomplete vaccination status among older adults in the community of $22.9 \%{ }^{(9)}$, with an accuracy of $3.5 \%$ and a $95 \%$ confidence interval, for a finite population of 36,703 people aged 60 years old or older, reaching a sample of 576 older adults.

A total of 823 older adults were interviewed, of whom 247 presented cognitive decline. Thus, 576 of them made up the final sample of the study.

\section{DATA COlLECTION}

Data collection was carried out at the older adults' house, from March 2017 to June 2018, through direct interviews, which were carried out by ten interviewers, who underwent training, qualification and approach on ethical research issues. Prior to the interview, cognitive screening was carried out through the Mini Mental State Examination (MMSE), with the translated and validated version in Brazil, considering the cutoff points proposed by Brucki et al. ${ }^{(10)}$. The sociodemographic characteristics were obtained through the application of a structured questionnaire, prepared by the members of the Research Group on Public Health, based on the literature and on the expertise of the researchers.

Basic activities of daily living (BADL) were measured using the Katz Index, adapted to the Brazilian context and composed of six items that measure the individual's performance in self-care activities ${ }^{(11)}$. For IADL (Instrumental activities of daily living), the Lawton \& Brody Scale was used, which allows classification through a score ranging from seven (highest level of dependence) to 21 points (complete independence), categorizing the older adult as a totally dependent ( 7 points), partially ( 8 to 20 points) and independent $(21 \text { points })^{(12)}$.

As for the vaccination status, the data were identified by analyzing the vaccination card of older adults, according to recommendations from the Ministry of Health ${ }^{(3)}$ (Chart 1). Cards with vaccines are considered adequate as specified in Chart 1. It is noteworthy that routine vaccines were selected in the older adults' vaccination calendar and made available in the Unified Health System - Sistema Único de Saúde (SUS), by the Municipal Health Department of Uberaba (MG), from 2017 to 2018. In Brazil, since 2017 the vaccine against yellow fever is recommended for older adults who live or have to move to areas of transmission of the disease ${ }^{(13)}$, as the setting of this research ${ }^{(14)}$. 
Chart 1 - Routine vaccines available through the Unified Health System of older adults' vaccination calendar.

\begin{tabular}{|l|c|c|}
\hline \multirow{4}{*}{$\begin{array}{l}\text { 60 years } \\
\text { old or } \\
\text { more }\end{array}$} & Vepatitis B & Three doses (0-1-6 months) \\
\cline { 2 - 3 } & $\begin{array}{c}\text { Yellow fever } \\
\text { (H1N1) }\end{array}$ & One dose \\
\cline { 2 - 3 } & $\begin{array}{c}\text { Diphtheria and } \\
\text { Tetanus (dT) }\end{array}$ & $\begin{array}{c}\text { Annual dose } \\
\text { The dose every ten years } \\
\text { (reinforcements) } \\
\text { doses of this vaccine. }\end{array}$ \\
\hline
\end{tabular}

Source: Brazil, $2017^{(3)}$.

The variables used in this study were: gender (female; male), age group ( $60+70 ; 70+80 ; 80$ or more), marital status (single; living with partner; widowed; separated/divorced), education, in complete years of study (none; $1+5 ; 5$ or more), individual monthly income, in minimum wages ( $\leq 1$; $>1$ ), housing arrangement (accompanied; alone), functional capacity (BADL: dependent and independent; IADL: totally dependent, partially dependent and independent), vaccination status (complete; incomplete; absence of vaccination card).

\section{Data ANALYSIS}

An electronic database was built, using the Excel ${ }^{\circledR}$ program, with double entry. After checking the inconsistencies between the two databases and correcting them, the database was imported into the Statistical Package for the Social Sciences (SPSS ${ }^{\circledR}$ ) version 22.0 for analysis.

The data were submitted to the analysis of absolute and relative frequency. To check the factors associated with the vaccination status, a preliminary bivariate analysis was performed using the Chi-square test. The variables of interest that met the established criterion $(p \leq 0.10)$ were introduced in the multinomial logistic regression model $(\mathrm{p}<0.05)$. The outcome was considered the vaccination status. In the predictive variables, it was considered: gender, age group, marital status, education, individual monthly income, housing arrangement and functional capacity for BADL and IADL. For bivariate analyzes and multinomial logistic regression, the following variables were dichotomized: age group ( $60+80$ years old; 80 years old or more), marital status (with and without partner), individual monthly income $(\leq 1 ;>1)$ and functional capacity for IADL (totally/partially dependent; independent). The education variable was used in the quantitative form, considering the complete years of study.

\section{ETHICAL ASPECTS}

The project was approved by the UFTM Human Research Ethics Committee, Protocol 2.053.520, in May 2017, following all the precepts of Resolution 466/12, of the National Health Council. After the consent of the older adult and the signing of the Informed Consent Form, the interview was conducted.

\section{RESULTS}

There was a predominance of women (65.3\%), in the age group of $60+70$ years old (42.5\%), who had a partner (45.3\%), with $1+5$ years of education (45.7\%), individual monthly income $\leq 1$ (53.6\%), living with someone (82.8\%), independent in the BADLs (94.3\%) and partially dependents in IADL (68.6\%). Among the older adults, a higher percentage was with incomplete vaccination status (36.1\%). Among the missing vaccines, Hepatitis B (30.4\%) and dT (16.1\%) were the most frequent (Table 1$)$.

Table 1 shows the vaccination status of older adults in the community of Uberaba (MG).

Table 1 - Vaccination status of older adults in the community Uberaba, MG, Brazil, 2017-2018.

\begin{tabular}{lcc}
\hline Variables & $\mathbf{n}$ & $\%$ \\
\hline Vaccination status & 188 & 32.6 \\
Complete & 208 & 36.1 \\
Incomplete & 180 & 31.3 \\
Absence of vaccination card & & \\
\hline Missing vaccines & 246 & 30.4 \\
Hepatitis B & 130 & 16.1 \\
Diphtheria and Tetanus (dT) & 120 & 14.8 \\
Yellow fever & 22 & 2.7 \\
\hline Seasonal Influenza (H1N1) & & \\
\hline
\end{tabular}

To check the factors associated with the vaccination status, a preliminary bivariate analysis was performed. Variables that met the adopted criterion $(p \leq 0.10)$ were inserted in the multivariate model: individual monthly income $(\mathrm{p}=0.013)$, home arrangement $(\mathrm{p}=0.039)$ and IADL $(\mathrm{p}=0.080)$ (Table 2$)$.

Table 2 presents the preliminary bivariate analysis of sociodemographic variables and functional capacity, according to the vaccination status of older adults in the community of Uberaba (MG).

The following factors were consolidated associated with the incomplete vaccination status: individual monthly income $\leq 1$ minimum wage $(\mathrm{p}=0.002)$ and single-person housing arrangement $(\mathrm{p}=0.010)$. For the absence of the vaccination card, the associated factor was the lowest level of education $(\mathrm{p}=0.039)$.

Table 3 presents the final model of multinomial logistic regression for sociodemographic variables and functional capacity in IADL associated with the vaccination status of older adults in the community of Uberaba (MG). 
Table 2 - Bivariate analysis with sociodemographic variables and functional capacity according to the vaccination status of older adults in the community - Uberaba, MG, Brazil, 2017-2018.

\begin{tabular}{|c|c|c|c|c|c|c|c|}
\hline & \multicolumn{6}{|c|}{ Vaccination status } & \multirow[t]{3}{*}{$\mathbf{p}^{*}$} \\
\hline & \multicolumn{2}{|c|}{ Complete } & \multicolumn{2}{|c|}{ Incomplete } & \multicolumn{2}{|c|}{ Absence of vaccination card } & \\
\hline & $\mathbf{n}$ & $\%$ & $\mathbf{n}$ & $\%$ & $\mathbf{n}$ & $\%$ & \\
\hline Gender & & & & & & & 0.900 \\
\hline Female & 125 & 33.2 & 135 & 35.9 & 116 & 30.9 & \\
\hline Male & 63 & 31.5 & 73 & 36.5 & 64 & 32.0 & \\
\hline Age group & & & & & & & 0.480 \\
\hline $60+80$ & 156 & 32.0 & 174 & 35.7 & 157 & 32.2 & \\
\hline 80 or more & 32 & 36.0 & 34 & 38.2 & 23 & 25.8 & \\
\hline Marital status & & & & & & & 0.566 \\
\hline With a partner & 84 & 32.2 & 100 & 38.3 & 77 & 29.5 & \\
\hline No partner & 104 & 33.0 & 108 & 34.3 & 103 & 32.7 & \\
\hline Individual monthly income & & & & & & & 0.013 \\
\hline$\leq 1$ & 112 & 36.2 & 95 & 30.7 & 102 & 33.0 & \\
\hline$>1$ & 76 & 28.5 & 113 & 42.3 & 78 & 29.2 & \\
\hline Home arrangement & & & & & & & 0.039 \\
\hline Alone & 40 & 40.4 & 25 & 25.3 & 34 & 34.3 & \\
\hline Living with someone & 148 & 31.0 & 183 & 38.4 & 146 & 30.6 & \\
\hline BADL** & & & & & & & 0.948 \\
\hline Independent & 178 & 32.8 & 196 & 36.1 & 169 & 31.1 & \\
\hline Dependent & 10 & 30.3 & 12 & 36.4 & 11 & 33.3 & \\
\hline IADL*** & & & & & & & 0.080 \\
\hline Independent & 70 & 39.1 & 60 & 33.5 & 49 & 27.4 & \\
\hline Totally/partially dependent & 118 & 29.7 & 148 & 37.3 & 131 & 33.0 & \\
\hline
\end{tabular}

Note: ${ }^{p} p \leq 0,10$; **Basic activities of daily living; ${ }^{* * *}$ Instrumental activities of daily living.

Table 3 - Final multinomial logistic regression model for sociodemographic variables and functional capacity in IADL associated with the vaccination status of older adults in the community - Uberaba, MG, Brazil, 2017-2018.

\begin{tabular}{|c|c|c|c|c|c|c|}
\hline & \multicolumn{6}{|c|}{ Vaccination status } \\
\hline & \multicolumn{3}{|c|}{ Incomplete } & \multicolumn{3}{|c|}{ Absence of vaccination card } \\
\hline & OR* & $95 \% \mathrm{Cl}^{* *}$ & $\mathbf{p}^{* * *}$ & OR* $^{*}$ & $95 \% \mathrm{CI}^{* *}$ & $\mathbf{p}^{* * *}$ \\
\hline \multicolumn{7}{|l|}{ Individual monthly income } \\
\hline$>1$ & 1 & & & 1 & & \\
\hline$\leq 1$ & 1.95 & $(1.28-2.98)$ & 0.002 & 1.25 & $(0.81-1.93)$ & 0.231 \\
\hline \multicolumn{7}{|l|}{ Home arrangement } \\
\hline Living with someone & 1 & & & 1 & & \\
\hline Alone & 1.08 & $(1.19-3.63)$ & 0.010 & 1.17 & $(0.69-1.97)$ & 0.543 \\
\hline \multicolumn{7}{|l|}{ IADL**** } \\
\hline Independent & 1 & & & 1 & & \\
\hline Totally/partially dependent & 1.36 & $(0.92-2.01)$ & 0.107 & 1.32 & $(0.89-1.97)$ & 0.071 \\
\hline Education & 0.98 & $(0.94-1.03)$ & 0.227 & 1.40 & $(1.02-1.94)$ & 0.039 \\
\hline
\end{tabular}

Note: *OR: Odds Ratio; ${ }^{* *} \mathrm{CI}$ : Confidence interval; ${ }^{* * *} \mathrm{p}<0,05 ;{ }^{* * * *}$ Instrumental activities of daily living; 1- Reference category. 


\section{DISCUSSION}

The sociodemographic data obtained in this research corroborate national and international studies developed among community older adults, which verified a higher percentage of women ${ }^{(2,9,15-17)}$, with a higher age group ${ }^{(9,16)}$, who lived with a partner ${ }^{(2,14-15)}$ and with low income and education ${ }^{(2,15-16)}$. Regarding functional capacity, older adults were more dependent in the IADL than regarding the BADLs, which is similar to other studies conducted in the community ${ }^{(16-18)}$. The assessment of functional capacity is essential, as it allows to verify the need for care to older adults in activities to maintain and promote their own health ${ }^{(19)}$, such as vaccination.

The highest percentage of those with incomplete vaccination status differs from that identified in a survey conducted with older adults from the community of Teofilo Otoni (MG), in which $77.1 \%$ had a complete vaccination card, which, according to the authors, may indicate easy access to primary care services and adherence to immunization campaigns ${ }^{(10)}$. Adherence to vaccination among older adults is related to the recommendations of health professionals, in addition to the ease of access to the service and attitudes and beliefs in relation to this practice. Additionally, older adults who have a closer relationship with health services are more likely to obtain information and encouragement for this practice of self-care ${ }^{(20-21)}$.

Among older adults, there is a higher incidence of certain infectious diseases, making them important causes of morbidity and mortality in this population, which highlights the importance of vaccination, which is the best prevention strategy ${ }^{(2)}$. Thus, it is essential that health professionals, especially the nursing team, advise older adults about the need to keep the vaccination card updated ${ }^{(22)}$, either through vaccination campaigns, active search, health education, waiting room, among other possibilities.

The study demonstrated low adherence to the Hepatitis $B$ vaccine. A research conducted in Lebanon, with individuals aged 14 to 89 years old, found that among those who had hepatitis B virus infection, $26 \%$ were older adults ${ }^{(23)}$. A study carried out in Minas Gerais, including people aged 60 or over, found a decrease in cases of hepatitis B from 2007 onwards. However, they highlight that among the reported cases, most individuals had not been immunized or had an incomplete vaccination schedule for hepatitis $\mathrm{B}^{(24)}$. In Brazil, in 2016 the offer of the hepatitis B vaccine was extended to all population groups, regardless of age group or vulnerable condition, especially older adults, who with the increase in life expectancy and the rise of sexual activity without safe practices are exposed to the risk of acquiring sexually transmitted infections ${ }^{(25)}$. An international survey, carried out in the Philippines, found that the high prevalence rates of infection with the hepatitis $B$ virus were related to a lack of prevention, through vaccines, and effective treatment, when necessary. Thus, it is emphasized the need for better training of health professionals ${ }^{(26)}$ for actions that make it possible to increase vaccine coverage, such as Hepatitis $\mathrm{B}$, in this age group.

Regarding the $\mathrm{dT}$ vaccine, an international multicentric research found that $53 \%$ of the cases of individuals with tetanus were older adults, with immunization being a critical factor, with regard to the prevention of cases, establishment of the disease and evolution to death, especially among those with more advanced age ${ }^{(27)}$. During the human aging process, the serum levels of tetanus antitoxin drop, which along with other factors, such as the lack of completeness of the vaccination schedule, including reinforcements, may contribute to the increase in the number of cases of the disease $^{(8)}$. Furthermore, in Brazil, in relation to the cases of diphtheria, considering the decline in immunity over time and the lack of adherence to the complete scheme with the vaccine reinforcements, in a context of intense reception of immigrants in the country, it stands out that these factors can contribute to the increase in the number of cases ${ }^{(28)}$.

Regarding the yellow fever vaccine, changes have occurred in Brazil since 2017 $7^{(13)}$. According to recommendation of the Ministry of Health, only older adults who live or have to move to areas where the transmission of the disease occur should be immunized, and it is essential that the health professional evaluates the risk and the benefit for the first vaccination $^{(13)}$. Thus, it is possible, although not investigated, that part of the older adults did not receive the vaccine, due to medical recommendations. On the other hand, the high percentage of older adults immunized against Seasonal Influenza may be related to the performance of vaccination campaigns, dissemination in the media, in addition to access to primary health care services available to the population.

As in this study, researches conducted with Brazilian older adults showed lower income as a negative condition for adherence to vaccination ${ }^{(2,15-16)}$. A national investigation carried out with older adults identified that those who lived alone were more susceptible to health problems and worse physical and behavioral conditions ${ }^{(29)}$. However, it is noteworthy that the involvement of other persons in health care, as a partner, is essential at this stage of life, since it can contribute to the adoption of self-care practices, such as vaccination, through the encouragement and monitoring of the health service ${ }^{(30)}$. Thus, attention should be given by nurses to this public in order to offer and identify social support networks that can contribute to accessing and adhering to immunization actions.

The lowest level of education was associated with the absence of the vaccination card. It is emphasized that the educational level can directly affect the understanding of the benefits of immunization and the information provided by health professionals ${ }^{(15)}$. In addition to the association with income, people with higher education tend to seek health services less frequently ${ }^{(31)}$. In this context, it is assumed that the social and economic characteristics of the older adults interviewed may have contributed to non-adherence and/ or the search for immunization services.

Adherence to vaccination may differ according to specific groups and places of residence, which is why it is necessary to provide guidance and awareness to these older adults and family members about vaccine's importance to prolong their good health. In this perspective, nurses play an important role, since the nursing team is responsible for carrying out the immunization actions. Thus, practices such as health 
education to raise awareness among the older adults, family members and the community, the dissemination of vaccines available for this age group, proper vaccination card screening, active search for those who are absent, among other aspects, should be implemented in the routine of services.

The research has as limitations the cross-sectional design, which makes the causality relationship of the studied events unfeasible and the exclusion of older adults with cognitive impairment that may have favored a healthier sample. However, the possibility of selection bias was minimized, once all eligible older adults were interviewed. The results advance in the production of scientific knowledge and reinforce the discussions about the relevance of maintaining the vaccination calendar of the older adult, often conditioned to the Seasonal Influenza vaccine in this age group.

Therefore, the identification of factors associated with the vaccination status, at this stage of life, can contribute to the establishment of actions aimed at expanding vaccination coverage for this age group, to favor the maintenance of health, the prevention of diseases and the reduction of costs in treatments related to immunopreventable diseases.

\section{CONCLUSION}

The evaluation of the sociodemographic profile and functional capacity of the older adults evaluated follows the national trend, with a predominance of women, older age group, low education and income, with a partner and living with someone, in addition to being independent in BADL and partially dependent on IADL. With the highest percentage of older adults with incomplete vaccination status, the Hepatitis B vaccine stood out as less frequent and there was a greater adherence to Seasonal Influenza. Thus, it is inferred the need to disclose the changes in the vaccination calendar of the older adults carried out in recent years in Brazil, reinforcing the importance of the continuity and maintenance of immunization at this stage of life.

The incomplete vaccination status was associated with low individual income and the single-person housing arrangement. The absence of the vaccination card was associated with lower education, showing that the characteristics of the population must be considered for the establishment of actions aimed at the prevention of immunopreventable diseases.

The importance of nursing working in primary health care is shown to expand vaccination coverage, since they did not fully reach the investigated population. In addition, low income and education, as well as the single-person housing arrangement, are aspects that must be observed for the development of health promotion and disease prevention strategies, targeted at this population segment.

\section{RESUMO}

Objetivo: Descrever as características sociodemográficas, a capacidade funcional e a situação vacinal de idosos, e verificar os fatores associados à situação vacinal incompleta e à ausência do cartão de vacinas. Método: Estudo transversal e analítico conduzido com idosos residentes na zona urbana de Uberaba (MG). Procedeu-se às análises descritiva, bivariada e regressão logística multinomial $(p<0,05)$. Resultados: Participaram 576 idosos. Predominaram os idosos do sexo feminino, na faixa etária de 70 -80 anos, com companheiro, baixa escolaridade e renda, que moravam acompanhados, independentes nas atividades básicas da vida diária e com dependência parcial nas atividades instrumentais. $\mathrm{O}$ maior percentual foi para os idosos que possuíam situação vacinal incompleta, sobretudo em relação à ausência da imunização para Hepatite B. Foram associados à situação vacinal incompleta a renda individual mensal $\leq 1$ salário mínimo $(p=0,002)$ e o arranjo de moradia unipessoal $(p=0,010)$; e à ausência do cartão de vacinas, a menor escolaridade $(p=0,039)$. Conclusão: As baixas renda e escolaridade, bem como residir sozinho, são fatores associados às situações vacinais inadequadas dos idosos da comunidade. Ressalta-se a necessidade de que o enfermeiro da atenção primária desenvolva estratégias para aumentar a cobertura vacinal entre os idosos com essas características.

\section{DESCRITORES}

Idoso; Vacinas; Imunização; Saúde do Idoso; Enfermagem Geriátrica.

\section{RESUMEN}

Objetivo: Describir las características sociodemográficas, la capacidad funcional y la situación vacunal de los adultos mayores y comprobar los factores asociados con la situación vacunal incompleta y la ausencia del carnet de vacunación. Método: Se trata de un estudio transversal y analítico llevado a cabo con adultos mayores residentes en el área urbana de Uberaba, Minas Gerais, mediante un análisis descriptivo, bivariado y de regresión logística multinomial $(\mathrm{p}<0,05)$. Resultados: Participaron 576 adultos mayores. Predominaban las mujeres de edad avanzada, $70-80$ años, con pareja, bajo nivel de escolaridad e ingresos, que vivían solas, independientes en las actividades básicas de la vida diaria y parcialmente dependientes de las actividades instrumentales. El porcentaje más alto correspondía a los adultos mayores que tenían un estado de vacunación incompleto, especialmente en lo que respecta a la ausencia de inmunización contra la hepatitis B. Los ingresos mensuales individuales $\leq 1$ salario mínimo $(p=0,002)$ y la disposición de una vivienda unifamiliar $(\mathrm{p}=0,010)$ estaban asociados con el estado de vacunación incompleta, y la ausencia del carnet de vacunación, con un nivel de escolaridad bajo ( $p=0,039)$. Conclusión: Los ingresos bajos y la educación, así como el hecho de vivir solo, son factores que están asociados a un estado de vacunación inadecuado en adultos mayores de la comunidad. Es importante que el enfermero de atención primaria desarrolle estrategias para aumentar la cobertura de vacunación entre los adultos mayores con dichas características.

\section{DESCRIPTORES}

Anciano; Vacunas; Inmunización; Salud del Anciano; Enfermería Geriátrica.

\section{REFERENCES}

1. Miranda GMD, Mendes ACG, Silva ALA. O envelhecimento populacional brasileiro: desafios e consequências sociais atuais e futuras. Rev Bras Geriatr Gerontol. 2016;19(3):507-19. doi: https://doi.org/10.1590/1809-98232016019.150140 
2. Oliveira LP, Lima ABS, Sá KVCS, Freitas DS, Aguiar MIF, Rabêlo PPC, et al. Perfil e situação vacinal de idosos em unidade da Estratégia Saúde da Família. Rev Pesq Saúde. [Internet]. 2016 [citado 2019 nov. 18];17(1):23-6. Disponível em: http://www.periodicoseletronicos. ufma.br/index.php/revistahuufma/article/view/5498/3363

3. Brasil. Ministério da Saúde. Calendário Nacional de Vacinação 2017 [Internet]. Brasília: MS; 2017 [citado 2018 nov. 18]. Disponível em: http://portalarquivos.saude.gov.br/images/pdf/2017/outubro/03/Calendario-2017-atualizado.pdf

4. Monteiro CN, Gianini RJ, Stopa SR, Segri NJ, Barros MBA, Cesar CLG, et al. Cobertura vacinal e utilização do SUS para vacinação contra gripe e pneumonia em adultos e idosos com diabetes autorreferida, no município de São Paulo, 2003, 2008 e 2015. Epidemiol Serv Saúde. 2018;27(2):e2017272. doi: https://doi.org/10.5123/s1679-49742018000200006

5. Hellfritzsch M, Thomsen RW, Baggesen LM, Larsen FB, Sørensen HT, Christiansen CF. Lifestyle, socioeconomic characteristics, and medical history of elderly persons who receive seasonal influenza vaccination in a tax-supported healthcare system. Vaccine. 2017;35(18):2396403. doi: 10.1016/j.vaccine.2017.03.040

6. Manzoli L, Gabutti G, Siliquini R, Flacco ME, Villari P, Ricciardi W. Association between vaccination coverage decline and influenza incidence rise among Italian elderly. Eur J Public Health. 2019;28(4):740-2. doi: https://doi.org/10.1093/eurpub/cky053

7. Bekker-Grob EW, Veldwijk J, Jonker M, Donkers B, Huisman J, Buis S, et al. The impact of vaccination and patient characteristics on influenza vaccination uptake of elderly people: a discrete choice experiment. Vaccine. 2018;36(11):1467-76. doi:10.1016/j. vaccine.2018.01.054

8. Santos El, Trigueiro GL, Coutinho LP, Mazoni TE, Bernardes MMR, Santos VO. Imunização dos idosos na América Latina: revisão integrativa da literatura. Cient Ciênc Biol Saúde. 2014;16(3):221-7. doi: http://dx.doi.org/10.17921/2447-8938.2014v16n3p\%25p

9. Pimenta FB, Pinho L, Silveira MF, Botelho ACC. Fatores associados a doenças crônicas em idosos atendidos pela Estratégia de Saúde da Família. Ciênc Saúde Coletiva. 2015; 20(8):2489-98. doi: http://dx.doi.org/10.1590/1413-81232015208.11742014.

10. Brucki SMD, Nitrini R, Caramelli P, Bertolucci PHF, Okamoto IH. Sugestões para o uso do mini-exame do estado mental no Brasil. Arq Neuro Psiquiatr. 2003;61(3B):777-781. doi: http://dx.doi.org/10.1590/S0004-282X2003000500014

11. Lino VTS, Pereira SEM, Camacho LAB, Ribeiro Filho ST, Buksman S. Adaptação transcultural da Escala de Independência em Atividades de Vida Diária (Escala de Katz). Cad Saúde Pública. 2008;24(1):103-12. doi: http://dx.doi.org/10.1590/S0102-311X2008000100010

12. Lawton MP, Brody EM. Assessment of older people: self-maintaining and instrumental activities of daily living. Gerontologist. 1969;9(3):17986. doi: https://doi.org/10.1093/geront/9.3_Part_1.179

13. Brasil. Ministério da Saúde. Nota informativa n. 94, de 2017. Orientações e indicações de dose única da vacina febre amarela [Internet]. Brasília; 2017 [citado 2017 nov. 16]. Disponível em: https://sbim.org.br/images/files/nota-ms-fa-170410.pdf

14. Brasil. Ministério da Saúde. Municípios conforme áreas de recomendação para vacina febre amarela [Internet]. Brasília; 2017 [citado 2020 jul. 01]. Disponível em: https://www.saude.gov.br/images/listavacinacaofa.pdf

15. Neves RG, Duro SMS, Tomasi E. Vacinação contra influenza em idosos de Pelotas-RS, 2014: um estudo transversal de base populacional. Epidemiol Serv Saúde. 2016;25(4):755-66. doi: http://dx.doi.org/10.5123/s1679-49742016000400009

16. Andrade J, Ayres JA, Alencar RA, Duarte MTC, Parada CMGL. Vulnerabilidade de idosos a infecções sexualmente transmissíveis. Acta Paul Enferm. 2017;30(1):8-15. doi: http://dx.doi.org/10.1590/1982-0194201700003

17. Zhang Q, Qi W, Wang X, Zhang Y, Xu Y, Qin S, et al. Epidemiology of hepatitis b and hepatitis c infections and benefits of programs for hepatitis prevention in northeastern China: a cross-sectional study. Clin Infect Dis. 2016;62(1):305-12. doi: 10.1093/cid/civ859

18. Gavasso WC, Beltrame V. Capacidade funcional e morbidades referidas: uma análise comparativa em idosos. Rev Bras Geriatr Gerontol. 2017;20(3):399-409. doi: http://dx.doi.org/10.1590/1981-22562017020.160080

19. Souza F, Alexsandra MD. Condição multidimensional de saúde dos idosos inscritos na estratégia saúde da família. Arq Ciênc Saúde. 2015;22(4):73-7. doi: https://doi.org/10.17696/2318-3691.22.4.2015.157

20. Moura RF, Andrade FB, Duarte YAO, Lebrão ML, Antunes JLF. Fatores associados à adesão à vacinação antiinfluenza em idosos não institucionalizados, São Paulo, Brasil. Cad Saúde Pública. 2015;31(10):2157-68. doi: http://dx.doi.org/10.1590/0102-311X00065414

21. Kan T, Zhang J. Factors influencing seasonal influenza vaccination behavior among elderly people: a systematic review. Public Health. 2018;156:67-78. doi:10.1016/j.puhe.2017.12.007

22. Ellen M. Fatores que influenciam as taxas de vacinação contra influenza em idosos: perspectivas dos enfermeiros. J Nurs Manag. 2017; 26(2):158-66. doi:10.1111/jonm.12528

23. Rached AA, Kheir SA, Saba J, Ammar W. Epidemiology of hepatitis B and hepatitis C in Lebanon. Arab J Gastroenterol. 2016;17(1):29-33. doi: 10.1016/j.ajg.2016.01.002

24. Gusmão BM, Rocha AP, Fernandes MBS, Dias OV, Costa SM, Pereira FS. Análise do perfil sociodemográfico de notificados para hepatite B e imunização contra a doença. Rev Online Pesq Cuid Fundam. 2017;9(3):627-33. doi: 10.9789/2175-5361.2017.v9i3.627-633

25. Brasil. Ministério da Saúde; Secretaria de Vigilância à Saúde; Departamento de Vigilância das Doenças Transmissíveis. Nota informativa n.149, de 2015. Informa as mudanças no Calendário Nacional de Vacinação para o ano 2016 [Internet]. Brasília; 2016 [citado 2019 out. 10]. Disponível em: http://www.aids.gov.br/pt-br/legislacao/nota-informativa-no-1492015

26. Gisch RG, Sollano Júnior JD, Laparasan A, Ong JP. Chronic hepatitis B virus in the Philippines. J Clin Gastroenterol Hepatol. 2016;31(5):94552. doi: https://doi.org/10.1111/jgh.13258

27. Tosun S, Batirel A, Oluk AI, Aksoy F, Puca E, Bénézit F, et al. Tetanus in adults: results of the multicenter IDIRI study. Eur J Clin. Microbiol Infect Dis. 2017;36(8):455-62. doi: 10.1007/s10096-017-2954-3

28. Benedetti MSG. Difteria em Roraima: uma análise epidemiológica no período de 1989 a 2017. Braz J Health Rev. 2019;2(1):571-9.

29. Negrini ELD, Nascimento CF, Silva A, Antunes JLF. Quem são e como vivem idosos que vivem sozinhos no Brasil. Rev Bras Geriatr Gerontol. 2018;21(5):542-50. doi: https://doi.org/10.1590/1981-22562018021.180101. 
30. Levorato CD, Mello LM, Silva AS, Nunes AA. Fatores associados à procura por serviços de saúde numa perspectiva relacional de gênero. Ciênc Saúde Coletiva. 2014;19(4):1263-74. doi: http://dx.doi.org/10.1590/1413-81232014194.01242013

31. Almeida APSC, Nunes BP, Duro SMS, Fachinni LA. Determinantes socioeconômicos do acesso a serviços de saúde em idosos: revisão sistemática. Rev Saúde Pública. 2017;51(1):50. doi: http://dx.doi.org/10.1590/s1518-8787.2017051006661

Financial support:

Conselho Nacional de Desenvolvimento Científico e Tecnológico. Process 301704/2012-0.

Fundação de Amparo à Pesquisa do Estado de Minas Gerais. Process APQ-00866-12. 